\title{
INNOVATION PROCESS AFFECTING FACTORS IN LATVIAN COMPANIES
}

\author{
Liga Braslin̦a ${ }^{1}$, Kaspars Viksne², Aivars Upenieks ${ }^{3}$, Anda Batraga ${ }^{4}$ \\ University of Latvia (Latvia)
}

\begin{abstract}
Innovation development process in companies is described by several challenges. One major problem is that there is much confusion about what it takes to develop innovations and what factors affect the innovation development process. The paper focuses on innovation process' affecting factors in Latvian market. The paper's goal is to identify main factors that affect the innovation process the Latvian companies. After surveying 128 companies, authors concludes that many factors affects innovation process and none of them should be ignored. Following factors affect innovation process the most and therefore should be analysed more deeply: 1) The company's own resources; 2) High employees knowledge, competencies, skills and experience; 3) Investors' attraction opportunities. Research also emphasises importance of company's human resource, therefore authors suggest companies to look at their employees from different paradigm and approach them as the most valuable company's asset.

KEYWORDS: innovation, innovation process, innovation affecting factors.
\end{abstract}

JEL CODE: M31

\section{Introduction}

50 Years ago companies told customers what customers' needs are and how they can be satisfied. These times are over, and in contemporary society customers are the ones who define their needs and task for companies is to satisfy customers' needs in the highest possible degree. In contemporary business environment it is not easy task to do because customer needs are so specific. However, the newest technologies, inventions and discoveries gives companies an opportunities to provide innovative products that can satisfy most of the demanding customers' needs.

If company can constantly provide innovative products that can satisfy customer needs better than before, it can then be one of company's biggest competitive advantages. Problem is that there is much of confusion about what does it take to develop innovations and what factors affect the innovation development

1 Liga Braslina - University of Latvia, MBA. Scientific interests: marketing

E-mail: liga.braslina2@inbox.lv

Tel.: +3712659981

2 Kaspars Viksne - University of Latvia, MBA. Scientific interests: marketing

E-mail: kaspars.viksne@gmail.com

Tel.: +371265 59228

3 Aivars Upenieks - University of Latvia, MBA, Scientific interests: international business

E-mail: aivars.upenieks@gmail.com

Tel.: +371 26677049

4 Anda Batraga - University of Latvia, PhD., Associate professor. Scientific interests: marketing

E-mail: anda.batraga@lu.lv

Tel.: +371 29224223 
process the most. Since the innovation development process is wide discipline, this paper focuses specifically on innovation process affecting factors in local, i.e., Latvian market.

The paper's goal is to identify factors that affect the innovation process the most in companies in Latvia. In order to accomplish the goal, authors have defined following tasks for paper: (1) By doing survey among Latvian companies identify to what extent Latvian companies are supplementing the market with new, innovative products and nature of these products; (2) By doing survey among Latvian companies reveal companies' opinions on what factors affect innovation process in their companies the most; (3) Evaluate factors that affects companies' sustainable growth the most, and (4) draw suggestions about better practise. Main methods that authors use for developing the research are content analysis statistical method, and graphical method. For practically-oriented study authors use quantitative survey method. For analysis of survey results descriptive comparisons of statistical data is applied.

\section{Theoretical findings}

\subsection{Identifying essence of innovation process}

In the last couple of decades the "innovation" term has become as one of the TOP 10 over-used terms in the business. Even though managers and business owners believe to fully understand the meaning of this complex term, practice shows the opposite. There are few obstacles on the way to the true understanding of innovation term. One of the factors that hinders the understanding, is that even scientists haven't agreed to one or few closely similar definitions of the innovation term. Therefore, hundreds of innovation term definitions have been and are being provided.

50 Years ago author Thomson explained innovation term as development, acceptance and application of new idea, process, product or service (Thomson, 1965). Authors of paper perceive this definition as incomplete because it mainly focuses only on new product. However, nowadays innovation term has acquired more broader meaning.

It is useful to explore how the most respectful and recognized institutions are explaining the controversial innovation term. OECD (Organisation for Economic Cooperation and Development) defines innovation as new or significantly improved product (goods or services), process, marketing or organizational methodology implementation. Even though the paper does not explore innovative marketing or organizational methodologies that the definition encompasses, because of definition`s directness according to products (and services), the authors believes this to be one of the most accurate definitions. From provided definition it follows that when speaking about the products and services, the innovation is understood not only as new but also as significantly improved product. This is important to understand, because innovation is not only completely new product (or service) that the world has never seen before (OECD, 2005).

\subsection{Identifying innovation development affecting factors}

The world's enterprises increasingly innovative development is of great importance when realizing that an innovation-oriented company is more competitive in a business environment. Currently, the term "innovation" has different meanings, where, for example, researchers Hoeve and Nieuwenhuis (Hoeve, Nieuwenhuis 2006) said that innovation is based on competition between businesses in the various strategies which companies have already implemented in 1950's. At that time were implemented approaches like effectiveness strategy, that uses management, based on cost-efficiencies; quality chain strategy based on variety of quality standards; strategy of the flexibility and innovativeness. Innovation process covers the entire process flow of the organization, starting the first initiation of idea until to the new product's or service's launch in the market (Woszczyna, 2014).

In their previously performed researches authors already have concluded that innovations can be company's main source of its competitive advantage. Summarizing the various research findings on the factors 
influencing the emergence of innovation, the authors are now concluding that the emergence of innovation influenced by the following factors: corporate culture, innovative attitude, planning process organization, interaction of planning processes and flexibility, human resources, technology and adaptation, the organizational structure of enterprise, resources availability, knowledge management, management style and leadership.

In continuation of the work, the authors outline the impact of each factor on the innovation occurring.

- Organisation culture - researcher found that in the early stages of innovation adoption one of the most dominant factor is the attitude in accepting a new product or capturing new ideas, where the company's organizational culture shows its attitude to risks and innovations, thus demonstrating its ability to influence and manage the innovations process in company, in addition to taking into account the organization's approach to collaboration and communication. Interestingly, the organizational culture is formed in its operation and the relationship between organizational culture and strategy are complex, which is often difficult to distinguish one from the other. In the investigation it is noted that the relationship between these two factors in the literature is reviewed from two aspects, firstly, the culture of the organization will be governed by the organization's strategy, which will contribute a variety of risks coming from new development strategies (Veugelers, Cassiman 1999; Cravens et al., 2002). Secondly, corporate strategy influence to the organizational culture is discussed in the literature. There are authors who claim that with a common vision of innovation, organizational strategic objectives will succeed to realize into organizational culture. (Vrakking, 1990; Calantone et al., 2002; Martins, Terblanche, 2003; Lemon, Sahota, 2004). As a result, it can be concluded that the organization's strategy represents the organizational culture and organizational culture can lead the corporate strategy.

- Novatoristic approach - some researchers also considers that the novatoristic approach is an important factor for business success and an essential prerequisite to have a tendency or pre-existing positive attitude towards accepting changes.

- The planning process of the organization - one of the most important changes needed in the innovation process is organization of space for ideas through the planning from the future to the past, which is one of the principles of the key success. This approach by the principles and expectations will ensure long-term context in which the shorter-term (tactical) decisions are to be aligned with the long-term strategy, thus better supporting the movement towards sustainable product innovations.

- Process interaction / company's flexibility - nowadays in the innovation process interactions between efficiency, quality, flexibility and innovation as such are highly important. A successful innovation process of products and services created for the market must be value-added, causing the interest of the consumer. Even within the innovation process must be agreement between research and development, production and work processes. Thus, the most valuable ideas are to be implemented in new forms with a high added value, as well as taken to new design and production workflows.

- Human Resources - creativity is one of the most important components in the process of innovation, where it best evolves in a collective process with the involvement of employees in order to increase the innovation potential, which is important from a human capital view. There an important role is played by the employee skills, the personality, motivation to innovate something new, as well as training, taking into account the different characteristics of employees. But for creativity it is required an addition concentration to knowledge creation as a process, where the information is produced in new knowledge forms and thus creates an additional knowledge base with added value for the successful innovation process. In the innovation process it is essential that staff should enough time resources, materials and finances, thus allowing new ideas to emerge. (Thamhain, 1990; Avlonitis et al., 1994; Pavitt, 2002). As authors have pointed out in their previously performed researches, the importance of company's employees cannot be underestimated. There are several reasons such as it is main source of potential upcoming innovation idea. Employees of the company often have 
the greatest knowledge of company's operative areas. This is not phenomena, but more like logical consequence because employees are deeply involved into the processes that are happening throughout the company. Employees often comes up with the valuable ideas what should be done better, and how something could be improved. Employees relationships with innovations are important, particularly team of scientists and technicians with qualification and experience in Research \& Development (De la Fuente, Galende, 2003).

- Technologies and adaptation - the Organization's ability to influence factors for technologies, where is important to deploy other technologies, technical skills and education, as well as technology strategy, thereby promoting innovation and innovative behaviour not only internally but also between organizations (Erdener, Dunn, 1995; Madsen et al., 2005). In organisations technologies have a support function, which reduces various stages in the innovation process.

- The company's organizational structure - integral part of the organization is a structure for determining the differentiation of the organization and its centralization.

- Resource availability - In organization's resources is planning and resource management is highly essential based on availability of technological resources, as well as financial resources. It is important how these resources are managed towards innovation.

- Knowledge management includes the organization's ability to learn, as well as skills in management of knowledge innovation, provided that there is awareness of both internal and external aspects of the organization knowledge.

- Management style and leadership - from the management perspective it is vital for its management style and leadership that it is able to influence the responsible staff in the organization. In addition, this aspect shows how leadership drives innovation, reflecting the organization's culture. The organization at the level of senior management has a commitment through a strategic sustainability plan. The company's clear commitment to the sustainability of mission and vision is one of the company's strengths. These aspects of sustainability are the most important element that defines the very basis of the formulation of the company's objectives and strategies.

- If the organization is moving away from the autocratic leadership style, it shows that the organization is of a democratic style that paves a stable path to innovation (Pearson et al, 1989; Roffe, 1999).

- Networking - in addition to take into account that the organization's networking with other businesses can change its attitude to innovation in a positive sense, which shows that the organization is able to be open to new ideas and learn from the experience of other organizations. This can play a big role in the organization of employees who can communicate with external organizations, in cooperation with them, thus facilitating interaction (Pavitt, 2002).

Given the above, it is clear that innovation processes in the company are influenced by the above-mentioned factors which by interacting with each other promote innovative environment in businesses.

\section{Findings about innovation driven factors in Latvian companies}

By taking into account previously identified innovation affecting factors as well as providing additional factors, the authors developed a survey and performed a surveyed-based study with the goal to practically evaluate which of the many innovation development factors are perceived to be the most important for companies in Latvia. In order to accomplish the goal, authors uttered 200 companies to answer survey's questions. Most of the respondents were randomly selected from Lursoft database by using criteria (more than 4 years in the market). In addition, the surveys were distributed to companies' representatives that were in authors' personal networking. Surveys were distributed and responses were gathered during in a 3 months period - from October 2014 until December 2014. After collecting all the responses, authors summarized and analysed respondents ' provided responses. The particular paper summarizes the survey`s results.

From 200 companies that were uttered, 128 representatives agreed to participate in the survey. In Figure 1 authors have graphically provided structure of respondent represented companies. 


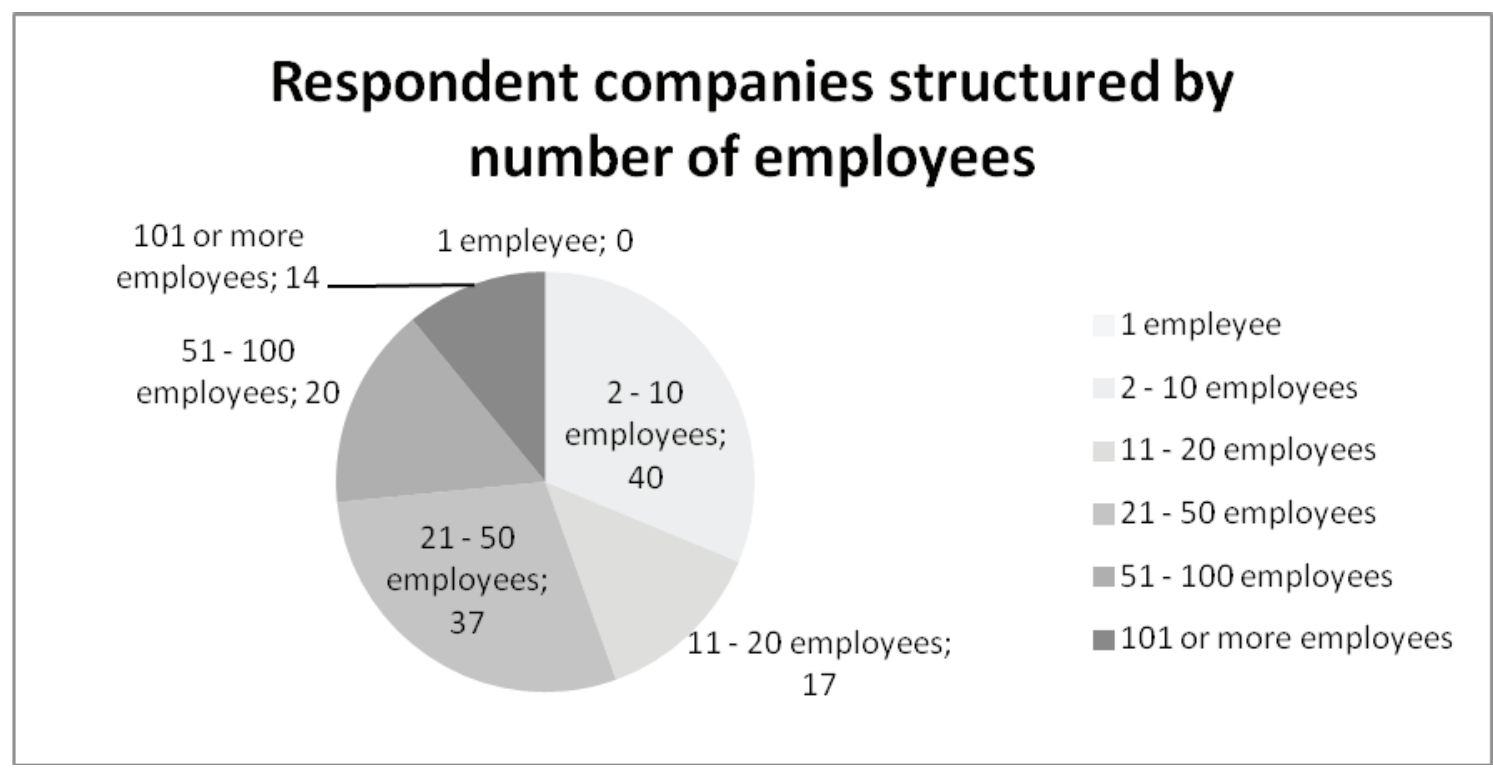

Figure 1. Surveyed companies structured by number of employees

Source: Authors' constructed figure after performed survey's results

As shows Figure 1 the most respondents (40) were from small companies that have $2-10$ employees, and small-medium sized businesses (37) that employs 21-50 employees.

Survey's main part was segmented into three groups of questions which had different purposes. $3^{\text {rd }}$ group of questions was included in survey with the purpose to understand respondents structure. Since authors provided brief summary of respondents structure, the paper will be continued with analysis of first two question groups.

With the help of the $1^{\text {st }}$ question group ( $1^{\text {st }}$ and $2^{\text {nd }}$ question) authors strive to understand to what extend Latvian companies are supplementing the market with innovative products.

In first question companies' representatives were asked to indicate how many innovative products their companies were released in market in years 2011, 2012, 2013 and 2014. Responses are summarized in Table 1 .

Table 1. Structure of Latvian companies` release of innovative products in 2011-2014

\begin{tabular}{|c|c|c|c|c|}
\hline \multirow{2}{*}{ Number of innovative products } & \multicolumn{4}{|c|}{ Year } \\
\cline { 2 - 5 } & 2011 & 2012 & 2013 & 2014 \\
\hline 0 & 33 & 36 & 33 & 28 \\
\hline $1-5$ & 79 & 48 & 42 & 48 \\
\hline $6-10$ & 8 & 20 & 21 & 28 \\
\hline $11-20$ & 8 & 12 & 17 & 9 \\
\hline $21-50$ & 0 & 11 & 12 & 12 \\
\hline 51 or more & 0 & 1 & 3 & 3 \\
\hline
\end{tabular}

Source: Authors' constructed table after performed survey's results

Information in Table 1 shows that between the years 2011-2014 most of the surveyed companies were releasing 1 to 5 new products in the market. Thus, the decrement can be observed in number of companies that were not releasing any innovative products in the market. Authors suggest that the driven forces in increment in number of released innovative products are mainly macro-economic factors, such us recovery and 
growth of county's economic, as well as IT industry which is healthy platform for development of innovations.

In theoretical findings section of the paper authors pointed out that nowadays innovation term has broader meaning than just new product that the world has never seen before. Therefore it is useful to understand what types of innovative products does the companies had in their portfolios in 2013. This was revealed through the survey's $2^{\text {nd }}$ question. More specific, the $2^{\text {nd }}$ question asked respondents to indicate what kind (and how many) of innovative products companies released in year 2013. Possible answers were:

- Completely new product that was not familiar for the world before.

- Existing product with new components, materials, ingredients.

- Existing product with new design.

- Existing product with new functions.

Responses are summarized in Table 2.

Table 2. Types and structue of innovative products that companies have released in 2013

\begin{tabular}{|c|c|c|c|c|}
\hline \multirow{2}{*}{$\begin{array}{c}\text { Number of } \\
\text { innovative } \\
\text { products }\end{array}$} & $\begin{array}{c}\text { Completely new product } \\
\text { that was not familiar for } \\
\text { the world before } \\
\text { new components, } \\
\text { materials, ingredients }\end{array}$ & $\begin{array}{c}\text { Existing product with } \\
\text { with new design }\end{array}$ & $\begin{array}{c}\text { Existing product } \\
\text { with new functions }\end{array}$ \\
\hline 0 & 96 & 49 & 44 & 64 \\
\hline $1-5$ & 32 & 44 & 48 & 40 \\
\hline $6-10$ & 0 & 31 & 32 & 2 \\
\hline $11-20$ & 0 & 2 & 1 & 3 \\
\hline $21-50$ & 0 & 2 & 3 & 1 \\
\hline 51 or more & 0 & 0 & 0 & 2 \\
\hline
\end{tabular}

Source: Authors' constructed table after performed survey's results

Table 2 shows that only 32 of 128 companies were releasing completely new product that the world haven't seen before. Thus, all of these 32 companies indicated that in 2013 they released only 1-5 innovative products. Most of the companies (85) indicated that in 2013 they released at least one existing product with the innovative design, and 79 companies indicated that in 2013 they released product that was innovative in terms of its components, materials and/or ingredients. When looking at structure of responses of $2^{\text {nd }}$ question, the logical consequence among the results can be observed - in 2013 the companies were releasing more innovative products that were less complex to produce (e.g. existing product with new design). At the same time companies produced less products that were more complex - truly new and previously unknown to the world. Such situation is being observed because most of the times production of less complex innovations such as design requires less financial, time and other resources. Thus, in some situations innovations that are more complex, are characterized by less certainty in the predicted sales results.

Goal for the second question group (Questions 3-4) was to reveal the respondents' thoughts about importance of different factors that affects company's innovations and sustainable growth. Therefore the $3^{\text {rd }}$ question asked respondents to share their opinions how important different factors are for innovation development in their represented companies. All these factors and well as their main indicators are summarized in Table 3. 
Table 3. Valuation of factors that affect innovation development in companies

\begin{tabular}{|c|c|c|c|}
\hline \multirow{2}{*}{ Factors that affect innovation development in companies } & \multicolumn{3}{|c|}{ Valuation statistics } \\
\hline & Average & Mode & Median \\
\hline The company's own resources & 4.34 & 5 & 5 \\
\hline High employees knowledge, competencies, skills and experience & 4.03 & 4 & 4 \\
\hline Investors' attraction opportunities & 3.88 & 5 & 4 \\
\hline Frequently monitored competitor activities & 3.69 & 3 & 4 \\
\hline Low innovation costs & 3.53 & 4 & 4 \\
\hline Low existing product's manufacturing (or service providing) costs & 3.50 & 4 & 4 \\
\hline Low innovation development process costs & 3.50 & 4 & 4 \\
\hline Innovation idea support in company's board & 3.44 & 4 & 4 \\
\hline Intuition of company's leading employees & 3.41 & 4 & 4 \\
\hline Loan attraction opportunities from credit institutions & 3.38 & 5 & 4 \\
\hline EU Funding receipt opportunities & 3.31 & 5 & 3 \\
\hline EU Innovation support systems & 3.16 & 5 & 3 \\
\hline High company's elasticity & 3.16 & 5 & 3 \\
\hline Management style in company & 3.13 & 4 & 3 \\
\hline Market researches & 3.09 & 3 & 3 \\
\hline Frequently renewed information about changes in market & 3.09 & 4 & 3 \\
\hline Government funding receipt opportunities & 3.00 & 5 & 3 \\
\hline Municipal funding receipt opportunities & 2.97 & 5 & 3 \\
\hline Luck & 2.83 & 2 & 2 \\
\hline Government innovation support systems & 2.81 & 5 & 3 \\
\hline Innovation-oriented organizational culture & 2.69 & 2 & 3 \\
\hline Municipal innovation support systems & 2.59 & 1 & 2 \\
\hline Partnership with scientific research institutions & 2.09 & 1 & 2 \\
\hline Innovation's relatedness with internet solutions & 1.81 & 1 & 1 \\
\hline
\end{tabular}

Source: Authors' constructed table after performed survey's results

From the Table 3 it can be concluded that the three most important factors that affect successful innovation releases in company are company's own resources. High employees knowledge, competencies, skills and experience, and Investors` attraction opportunities. At the same time the less important factors that affect innovative product releases in the companies are Municipal innovation support systems, Partnership with scientific research institutions, and innovation's relatedness with internet solutions. In order to expand the analysis of innovation affecting factors authors group every of given factors into five groups:

- Innovation development affecting financial factors.

- Innovation support systems.

- Innovation development affecting company's internal factors.

- Innovation development affecting company's human resource factors.

- Other innovation development affecting factors.

As the most important innovation development affecting financial factors respondents have indicated the company's own (financial) resources.

As the most important innovation development affecting innovation support systems factor respondents have indicated the EU innovation support systems. It may be because EU-level innovation support systems provides greater support that national level innovation support systems. 
As the most important innovation development affecting company's internal factors respondents have indicated frequently monitored competitor activities. It indicates that competitors are perceived as considerable source for possible product innovation.

As the most important innovation development affecting company's human resource factor respondents have indicated high employees knowledge, competencies, skills and experience.

Among other important factors that affect the innovation development in the company, the respondents have given the highest rating to factor "luck". However, when comparing with factors from other groups, the luck factor does not seem to be important factor. It indicates that the managers in Latvian companies are likely to be proactive.

After grouping the factors it can be concluded that the higher average rating is given to human resource factors group, and financial factors group. It Meanwhile the group of innovation support systems and group of other factors have received lower average rating.

Table 4 summarizes respondents`opinions about how important certain factors are to the company's sustainable growth.

Table 4. Valuation of factors that affect company's sustainable growth

\begin{tabular}{|l|c|c|c|}
\hline \multirow{2}{*}{ Factors that affect company`s sustainable growth } & \multicolumn{3}{c|}{ Valuation statistics } \\
\cline { 2 - 4 } & Average & Mode & Median \\
\hline Product development researches in company & 4.16 & 5 & 5 \\
\hline Promotion of internet marketing activities & 3.94 & 5 & 4 \\
\hline Promotion of non-internet marketing activities & 3.88 & 5 & 4 \\
\hline Accessibility to high-level human resources & 3.85 & 5 & 4 \\
\hline New client's attraction & 3.63 & 4 & 4 \\
\hline Clients' loyalty strengthening activities & 3.41 & 4 & 4 \\
\hline New export markets' acquisition & 3.34 & 5 & 3 \\
\hline Development of innovative products and services & 3.16 & 3 & 3 \\
\hline Strengthening of cooperative social responsibility & 3.13 & 3 & 3 \\
\hline Purposeful investments in company's human resources & 3.11 & 3 & 3 \\
\hline Effective change management & 3.09 & 3 & 3 \\
\hline Product development process optimization & 3.07 & 3 & 3 \\
\hline Usage of environmentally friendly technologies & 3.00 & 3 & 3 \\
\hline Information system in company & 2.91 & 1 & 3 \\
\hline Newest IT solutions' adaption in the company & 2.88 & 3 & 3 \\
\hline Organizational culture & 2.84 & 3 & 3 \\
\hline Competition level in the market & 2.69 & 3 & 3 \\
\hline Business environment in the country & 2.41 & 3 & 3 \\
\hline Tax system in country & 2.33 & 1 & 3 \\
\hline
\end{tabular}

Source: Authors' constructed table after performed survey's results

According to Table 4 companies believe that their long-term sustainable growth depends mostly from various internal environment factors such as (1) frequently performed product development researches, (2) promotion of internet as well as non-internet marketing activities. Also in this table qualitative employees have been indicated as one of the most important factors for companies' sustainable growth. From all the other factors organizational culture has the strongest ties with company's human resources (employees), therefore it is quite surprising to see that organizational culture has received $4^{\text {th }}$ lowest average rating -2.84 
of 5. Authors explain this contrast with the possible lack of understanding about organizational culture's potentially significant effect on employees productivity and overall effectiveness. By taking this into account, authors makes a proposal for companies not to underestimate the importance of company's organizational culture, because it has crucial impact on employees productivity and willingness to participate in the innovation process. Since the company's human resource has strong ties with the innovation development process, authors also proposes company managers to approach employees as the most valuable company's asset, because most of the times employees are decisive factor that determines company's goal accomplishments and success.

One of the other factors that respondents believe not to hive high influence on affecting the company's sustainable growth is the competition level in the market. It indicated that the companies in Latvia are more customer oriented and less competition oriented. Other two lowest rated factors are business environment in the country and tax system in country. Authors believe that these factors have been rated comparably low because these are external macro-environment factors that companies cannot affect.

\section{Conclusions}

Innovations are related not only to completely new and unseen products but also to existing products that are significantly improved in their functionality usage or design. Since the innovations are major driven force for economy and one of the prerequisites for company`s long term success, it is important to maintain stable innovation development process in the company. Supplementing market with innovative products is challenging task, therefore companies cannot issue innovative products every day. As authors' performed research shows, in last 4 years most of the surveyed companies were releasing 1 to 5 innovative products each year. Most of these products were existing products supplemented with new design, a bit less - existing products with the improved components, materials or ingredients; much less - completely new products that were totally unfamiliar to the world before. Such structure of innovative products is explained by their level of complexity - development of innovative product that is completely new and has not been in the market before, most of the times requires more financial, time and other investments, than existing product which is about to be significantly improved.

Innovation development process is affected by many factors and none of them should be underestimated, but there are several factors that should be taken into account and analyzed more carefully than others. Two of such factors that arises follows from authors' performed research are: (1) The company's own resources and (2) High employees knowledge, competencies, skills and experience, and (3) Investors' attraction opportunities. Therefore authors suggest companies to perceive these factors as the most important ones. By evaluating these factors and analyzing their offered opportunities to company, the company can maintain effective innovation development process. It can lead company to issuance of high-level innovation that would allow company to gain significant competitive advantage. It is also being revealed that the human resource factors have the most influence on successful innovation development. Similar conclusion is made when analyzing factors that affects company's sustainable growth. Results shows that company's sustainable growth is the most affected by frequently performed product development researches, promotion of internet and noninternet marketing activities, and accessibility to human resources. Therefore authors suggest companies to regularly perform wide range of product development and market researches. By taking into account this suggestion, companies will have greater chance to (1) find an opportunities for their products improvements, and (2) find a ways how to satisfy customer's needs in a higher degree. In addition authors propose companies to communicate with their customers by using both online and traditional communication channels. It will allow companies to deliver their message about their product's uniqueness and relevance to customers' needs. As an result companies will maintain their long term successful development and growth.

In contrast, company representatives approaches organizational culture as less important factor, even though it has strong ties with the company`s human resources. Since the human resource plays major role in 
innovation development process, authors proposes companies to approach employees as the most valuable company's asset, because it is decisive factor that determines company's success. By maintaining high-level organizational culture, companies would have done a major prerequisite for successful and game-changing innovation development.

\section{References}

Avlonitis, G. J., Kouremenos, A., Tzokas, N. (1994). Assessing the innovativeness of organizations and its antecedents: Project Innovstrat. European Journal of Marketing, Vol. 28, p. 5-19. Emerald Group Publishing Limited.

Calantone, R. J., Cavusgil, S. T., Zhao, Y. (2002). Learning orientation, firm innovation capability, and firm performance. Industrial Marketing Management, Vol. 31(6), p. 515-527. Elsevier Inc.

Coronado, D., Acosta, M., Fernandez, A. (2008). Attitudes to innovation in peripheral economic regions. Research Policy, Vol. 37, p. 1009-1021. Elsevier B.V.

Cravens, D. W., Piercy, N. F., Low, G. S. (2002). The innovation challenges of proactive cannibalization and discontinuous technology. European Business Review. Emerald Group Publishing Limited, Vol. 14 (4), p. 257-269.

De la Fuente, J. M., Galende, J. (2003). Internal factors determining a firm's innovative behavior. Research Policy, Vol. 32, p. 715-736. Elsevier B.V.

Erdener, C. B., Dunn, C. P. (1995). Organizational values and technological innovation: A cross-national comparison of corporate annual reports. International Journal of Management, Vol. 12/2, p. 197-203. John Wiley \& Sons Ltd and the British Academy of Management.

Hallstedt, S. I., Thompson, A. W., Lindahl, P. (2013). Key elements for implementing a strategic sustainability perspective in the product innovation process. Journal of Cleaner Production. Elsevier Ltd., Vol. 51, p. 277-288.

Hoeve, A., Nieuwenhuis, L. F. M. (2006). Learning routines in innovation processes. Journal of Workplace Learning, Vol. 18 (3), p. 171-185. MCB University Press (Emerald).

Lemon, M., Sahota, P. S. (2004). Organisational culture as a knowledge repository for increased innovative capacity. Technovation, Vol. 24, p. 483-498. Elsevier Ltd.

Martins, E. C., Terblanche, F. (2003). Building organisational culture that's timulates creativity and innovation. European Journal of Innovation Management, Vol. 6 (1), p. 64-74. Emerald Group Publishing Limited.

Merx-Chermin, M., Nijhof, W. J. (2005). Factors influencing knowledge creation and innovation in an organisation. Journal of European Industrial Training, Vol. 29, Issue 2, p. 135-147. MCB University Press (Emerald).

OECD. (2005). Oslo Manual - Guidlines for collecting and interpreting innovation data 3rd edition. OECD Publishing.

Pavitt, K. (2002). Innovating routines in the business firm: What corporate tasks should they be. Industrial and Corporate Change, Vol. 11 (1), p. 117-133. Oxford University Press.

Pearson, G. J., Pearson, A. W., Ball, D. F. (1989). Innovation in a mature industry: A case study of warp knitting in the U.K. Technovation, Vol. 9(8), p. 657-679. Elsevier Ltd.

Roffe, I. (1999). Innovation and creativity in organisations: A review of the implications for training and development. Journal of European Industrial Training, Vol. 23, p. 224-241. MCB University Press (Emerald).

Smith, M., Busi, M., Ball, P., Meer, R. V. D. (2008). Factors Influencing an Organisations ability to Manage Innovation: A Structured Literature Review and Conceptual Model. International Journal of Innovation Management, Vol. 12, Issue 4, p. 655-676. World Scientific Publishing.

Thamhain, H. J. (1990). Managing technologically innovative team efforts toward new product success. The Journal of Product Innovation Management, Vol. 7 (1), p. 5-18. Product Development \& Management Association, Wiley.

Veugelers, R., Cassiman, B. (1999). Make and buy in innovation strategies: Evidence from Belgian manufacturing firms. Research Policy, Vol. 28, p. 63-76. Elsevier B.V.

Vrakking, W. J. (1990). The innovative organization. Long Range Planning, Vol. 23 (2), p. 94-102. Elsevier Ltd.

Woszczyna K. S. (2014). Innovation processes in the social space of the organization. Regional Formation and Development Studies, Vol. 15, Issue 2, p. 220-229. Klaipeda University. 


\section{INOVACIJŲ LATVIJOS ORGANIZACIJOSE PROCESAMS ITAKA DARANTYS VEIKSNIAI}

Liga Braslinga, Kaspars Viksne, Aivars Upenieks, Anda Batraga

Latvijos universitetas (Latvija)

\section{SANTRAUKA}

Inovacijų kūrimo procesą įmonèse apibrěžia keletas iššūkių. Pagrindinė problema - yra daug neaiškumo kalbant apie tai, ko reikia, siekiant kurti inovacijas, kokie veiksniai turi įtakos šiam procesui. Straipsnyje aptariami Latvijos rinkai būdingi inovacijų procesą veikiantys veiksniai. Straipsnio tikslas - nustatyti pagrindinius veiksnius, kurie turi įtakos inovacijų Latvijos įmonèse procesui. Ištirtos 128 bendrovès ir padaryta išvada, kad inovacijų procesą veikia nemažai veiksnių, kurių nẻ vieno nereikètų ignoruoti. Didžiausią įtaką daro šie veiksniai, juos reikètų išsamiau analizuoti: 1) bendrovès ištekliai; 2) darbuotojų žinios, gebejjimai, igūdžiai ir patirtis; 3) investuotojų pritraukimo galimybès. Moksliniai tyrimai pabrèžia ir bendrovès žmogiškujų išteklių svarbą, todèl autoriai siūlo įmonèms žvelgti ị savo darbuotojus iš ịvairių paradigmų ir traktuoti juos kaip vertingiausią bendrovès turtą.

PAGRINDINIAI ŽODŽIAI: inovacijos, inovaciju procesas, inovacijoms įtakos turintys veiksniai.

JEL KLASIFIKACIJA: M31. 